\title{
A OPINIÃO DO CIDADÃO IMPORTA? A TRAMITAÇÃO DAS PROPOSIÇÕES LEGISLATIVAS MAIS VOTADAS NO PORTAL E-CIDADANIA DO SENADO FEDERAL
}

\author{
Andressa Butture Kniess ${ }^{1}$
}

\begin{abstract}
Resumo
A popularização das ferramentas digitais tornou quase que nulos os custos da participação política, permitindo que qualquer pessoa com acesso à internet se torne politicamente ativo sem precisar sair de casa. Entretanto, uma das preocupações da literatura é de que as manifestações enviadas pelos cidadãos não sejam devidamente consideradas pelos agentes públicos durante o processo decisório. O objetivo deste artigo é investigar se os resultados das votações ocorridas na Consulta Pública do Portal e-Cidadania, do Senado Federal, condizem com as decisões tomadas pelos legisladores. Para isso, são analisadas as 41 propostas legislativas que já tiveram a votação encerrada e receberam mais de 50 mil votos dos usuários do Portal. A metodologia de pesquisa é a Análise Documental e as variáveis aplicadas às proposições são "identificação", "ementa", "número de apoios", "número de rejeições", "autoria" e "situação da proposição legislativa". Resultados preliminares mostram que, dentre as matérias analisadas, 16 consistem em sugestões legislativas enviadas pelos próprios usuários do Portal e-Cidadania. Entretanto, algumas dessas sugestões buscam restringir liberdades democráticas ao propor a criminalização do comunismo e de movimentos sociais como o MST e o MTST.
\end{abstract}

Palavras-chave: Participação política online, Consulta pública, Senado Federal, Portal e-Cidadania.

\section{INTRODUÇÃO}

A popularização das ferramentas digitais proporcionou aos cidadãos novas formas de participação política. Qualquer pessoa com acesso à internet pode se tornar politicamente ativo sem nem precisar sair de casa. Além disso, essas ferramentas tornaram quase que nulos os custos da participação (VAN DETH, 2015). Consequentemente, o tema da participação política ganhou novas questões de pesquisa (GOMES, 2011) e passou a ser estudado através de diversas perspectivas e objetos: parlamentos digitais (FARIA, REHBEIN, 2015; FARIA, 2012), ativismo digital (KLANG, MADISON, 2016; CHRISTENSEN, 2011), astroturfing digital (KOVIC, et al, 2018; SILVA, 2015), participação em campanhas online (STROMER-GALLEY, 2000), etc.

Entretanto, a literatura especializada pondera que, em alguns casos, as possibilidades interativas da internet não são devidamente aproveitadas pelas instituições políticas e as manifestações enviadas pelos participantes não são, de fato, consideradas pelos agentes públicos (FARIA, 2012; MARQUES, 2010; FUNG, 2006, STROMER-GALLEY, 2000).

\footnotetext{
1 Doutoranda no Programa de Pós-Graduação em Ciência Política da Universidade Federal do Paraná. E-mail: andressakniess@gmail.com. ORCID: 0000-0002-1337-5376.
} 
Em vista disso, o objetivo deste trabalho é verificar se, no caso das consultas públicas do Portal e-Cidadania - ferramenta do Senado Federal que permite a qualquer cidadão apoiar ou rejeitar qualquer proposição legislativa que esteja em fase de tramitação naquela Casa - os resultados das votações dos participantes condizem com as decisões tomadas pelos legisladores. Para isso, são analisadas 41 proposições legislativas que receberam mais de 50 mil votos e que já tiveram a consulta pública encerrada. A técnica metodológica empregada é a Análise Documental (SÁ-SILVA, ALMEIDA, GUINDANI, 2009) e as variáveis aplicadas às proposições são "identificação", "ementa", "número de apoios", "número de rejeições", "autoria" e "situação da proposição legislativa".

Além desta introdução, o trabalho segue dividido em mais quatro seções. Primeiro, faz-se uma breve revisão de literatura de trabalhos que versam sobre a participação pública digital, especialmente sobre parlamentos digitais e consultas públicas. Em seguida, são esclarecidas as formas de participação disponibilizadas pelo Portal e-Cidadania e apresentadas as estratégias metodológicas aqui empregadas. A quarta seção apresenta os resultados. E, por fim, as discussões finais resumem os principais achados e os relacionam com a literatura mobilizada.

\section{SEÇÃO TEÓRICA}

Nas últimas décadas, a ampliação do acesso às tecnologias digitais expandiu o campo de estudos em Participação Política e impulsionou novas questões de pesquisa: a internet proporciona novas formas de participação e produz novos participantes? Quais são as diferenças entre a participação política online e a tradicional? E qual é a qualidade da participação que ocorre em ambiente digital? (GOMES, 2011). Neste trabalho, o objetivo é contribuir com as discussões a respeito de uma quarta questão: a participação que ocorre em ambientes digitais é, de fato, considerada por agentes políticos?

Está claro que a internet dispõe de ferramentas que podem facilitar a participação política. Ao reduzir seus custos a quase que nulos, as tecnologias digitais têm potencial para atrair cidadãos que, tradicionalmente, não participariam dessas atividades (AGGIO, SAMPAIO, 2013). Gomes (2005) define a democracia digital como uma oportunidade de superação das deficiências da democracia liberal. Mas pondera ela "não é um tipo de democracia, mas o uso de tecnologias para reforçar, corrigir ou melhorar as democracias existentes" (GOMES, 2018, p. 98). Stromer-Galley 
(2000), por sua vez, destaca que as plataformas digitais podem promover tanto discussões horizontais entre cidadãos, quanto interações verticais, entre cidadãos e elites políticas.

Contudo, as iniciativas de participação civil não devem ser um fim em si mesmas (AGGIO, SAMPAIO, 2013). E uma das preocupações dos especialistas da área é de que as capacidades interativas das ferramentas digitais não sejam totalmente aproveitadas pelas elites políticas (FARIA, 2012; FUNG, 2006, STROMER-GALLEY, 2000). Para Aggio e Sampaio (2013), uma iniciativa de participação eficiente precisa cumprir com as seguintes condições: 1) as ferramentas precisam ser ofertadas aos cidadãos e precisam dispor de design fácil e convidativo; 2) o sistema político precisa estar disposto a implementar as sugestões dos cidadãos; e 3) os cidadãos precisam estar dispostos a participar e a usufruir das ferramentas ofertadas.

Marques (2010) também contribui com essa discussão e apresenta três argumentos que podem explicar a ineficácia de algumas ferramentas digitais de participação: 1) a indisposição de representantes políticos e de instituições de Estado em envolver, efetivamente, os cidadãos no processo decisório; 2) os custos de implementação, que são reduzidos para os usuários, mas ampliados para as instituições, que acabam precisando processar um número mais extenso de tarefas e dados; e 3) o fato de que a maioria desses projetos é desenvolvida por profissionais da área de tecnologia e não por especialistas em democracia digital.

Van Deth (2015) expõe uma outra preocupação em relação ao tema. Segundo o autor, a internet permite que a participação política ocorra através de ações individualizadas. Além de votar, participar de uma manifestação ou apoiar um candidato (formas tradicionais de participação), os indivíduos podem, por exemplo, aderir ao boicote de uma determinada marca. De acordo com Van Deth (2015), esse é um tipo de atividade não política que pode ser realizada para fins políticos e que não requer nenhuma organização ou ação coletiva. "As a consequence, almost everybody can be politically active about everything at any moment in time ${ }^{2}$ " (VAN DETH, 2015, p.4). E, dessa forma, na perspectiva do autor, as ferramentas digitais acabam pouco contribuindo para mudanças políticas reais e apenas fortalecem o sentimento de envolvimento dos participantes.

Dentre os objetos de estudo analisados pelo campo da Participação Política, estão os parlamentos abertos. Para Faria e Rehbein (2015), uma Casa Legislativa pode ser considerada um parlamento aberto quando amplia a transparência, viabiliza manifestações de cidadãos através de

\footnotetext{
2 “Como consequência, quase todo mundo pode ser politicamente ativo sobre tudo a qualquer momento" (Tradução própria).
} 
ferramentas digitais de participação e é responsiva a essas manifestações (sendo este último o maior desafio).

Faria (2012) explica que os desafios que envolvem as iniciativas de e-democracia institucional compreendem tanto aspectos institucionais (como a resistência de agentes políticos, falta de recursos e de planejamento estratégico), quanto aspectos sociais. Essas ferramentas enfrentam problemas relacionados ao desequilíbrio de participação, uma vez que determinados assuntos demandam conhecimentos prévios daqueles que queiram participar. $\mathrm{O}$ autor salienta que o objetivo não é que todo cidadão queira e participe de qualquer debate sobre qualquer tema, mas é dever do poder público garantir condições mais inclusivas a essas ferramentas.

No que se refere ao Portal e-Democracia, da Câmara dos Deputados, Freitas, Lima e Lima (2015) identificam que, no caso das discussões a respeito do marco civil da internet, 89\% dos participantes eram homens, $68 \%$ brancos, $53 \%$ possuíam pós-graduação e $47 \%$ dispunham de renda mensal superior a 9 mil reais. Dados que demonstram que a população brasileira está subrepresentada nessa ferramenta de participação.

Faria (2012) também destaca que, na maioria das experiências de democracia eletrônica legislativa, há poucas implicações efetivas das participações. Ou seja, os cidadãos participam, mas é pouco comum que essas manifestações sejam consideradas durante o processo decisório. Como consequência, os participantes perdem a motivação quando não veem retorno as suas manifestações. E esse é um argumento também mobilizado por Gomes (2011):

[...] as pessoas participam de iniciativas quando as consideram uma oportunidade adequada para atingir fins desejáveis. Meios precisam ser vistos como oportunidades. Chamo oportunidades aquela conjunção de ocasiões e circunstâncias em que meios podem produzir fins desejáveis de maneira que os custos (a energia despendida, por exemplo) sejam largamente recompensados pelos benefícios (recompensas decorrentes de se alcançar a finalidade da ação). (p. 12).

Fung (2006) salienta que as formas de participação variam de acordo com três fatores: 1) quem participa: os processos são abertos a todos que queiram participar ou são restritos a representantes de grupos de interesse?; 2) como os participantes trocam informações: há espaços deliberativos?; e 3) qual é o impacto da participação do público? No que tange a esse último fator, Fung (2006) tem uma visão um pouco diversa daquelas apresentadas anteriormente: as pessoas participam mais para obter benefícios pessoais - instruir-se sobre um tema ou cumprir com um senso de dever cívico - do que para, efetivamente, influenciar no processo decisório. Ou seja, a maioria dos participantes tem pouca ou nenhuma expectativa de que as suas manifestações serão consideradas. 
No que tange ao segundo fator indicado por Fung (2006), o Portal e-Cidadania do Senado Federal, analisado por este trabalho, não oferece os mesmos recursos do Portal e-Democracia, da Câmara dos Deputados. Em estudo que compara o e-Democracia (plataforma que tem o intuito de promover discussões entre cidadãos e agentes políticos) com o Portal da Câmara dos Deputados, Mitozo, Marques e Mont'Alverne (2016) demonstram que, no primeiro caso, há maiores investimentos em espaços deliberativos. Em contrapartida, o e-Cidadania, como será demonstrado na seção seguinte, quase não oferece maneiras pelas quais os participantes possam interagir entre si ou com representantes políticos.

As consultas públicas são ferramentas que podem contribuir com a formação de parlamentos abertos, uma vez que viabilizam a participação de cidadãos. Segundo Shipley e Utz (2011), elas constituem um dos procedimentos de participação mais empregados por democracias do mundo todo. No Brasil, Almada e colegas (2019) mostram que, de fato, as consultas públicas são os mecanismos de e-participação mais despendidos pelo Poder Executivo Federal.

Entretanto, novamente é importante destacar que a participação não pode ser um fim em si mesma. Barros (2016) enumera quatro critérios para a avaliação de uma iniciativa de consulta pública online: 1) inclusividade e pluralismo: deve-se considerar as possíveis dificuldades que diferentes grupos de usuários venham a ter com a plataforma, o que pode comprometer a pluralidade de ideias;

2) recursos epistêmicos: no caso de temas mais complexos, o poder público deve ter a preocupação de explicar o assunto em linguagem leiga; 3) forma e empoderamento de participação: as plataformas não são ambientes neutros, ou seja, as suas características condicionam a participação cidadã; e 4) governo da iniciativa (termos de uso, identificação e moderação): os termos de uso são os usos esperados e admissíveis na plataforma, a identificação se refere à necessidade de os participantes se identificarem ou não e a moderação pode manter e civilidade do debate, mas também pode evitar temas controversos.

A seção abaixo esclarece quais são as possibilidades de participação disponibilizadas pelo Portal e-Cidadania, além de apresentar as estratégias metodológicas utilizadas neste trabalho. Em seguida, são apresentados os resultados desta pesquisa.

\section{OBJETO E MÉTODOS DE PESQUISA}


O objeto desta pesquisa são as proposições legislativas que, até o momento, receberam mais de 50 mil votos na ferramenta de Consulta Pública do Portal e-Cidadania, do Senado Federal. Destaca-se que são consideradas apenas as 41 matérias que já tiveram a consulta encerrada ${ }^{3}$.

Criado em 2012, o Portal e-Cidadania permite que qualquer pessoa participe das atividades do Senado Federal, através de três ferramentas: 1) Ideia Legislativa, 2) Evento Interativo e 3) Consulta Pública $^{4}$ - sendo necessário apenas realizar um cadastro que solicita nome completo, e-mail e unidade federativa de residência. A primeira ferramenta possibilita que os usuários enviem suas próprias sugestões legislativas - propondo a criação de uma nova lei ou a modificação de leis vigentes - ou votem em sugestões já enviadas por outros cidadãos. Quando uma sugestão recebe, pelo menos, 20 mil apoios, em até quatro meses, ela é encaminhada para a Comissão de Direitos Humanos e Legislação Participativa (CDH). Em seguida, um relator é designado a dar um parecer sobre a proposta que, por sua vez, é discutido pelos integrantes da $\mathrm{CDH}$. Quando aprovadas, as sugestões se transformam em propostas de lei que, de fato, passam a tramitar no Congresso Nacional ${ }^{5}$.

Eventos interativos, por sua vez, são audiências públicas e sabatinas transmitidas em tempo real e que podem ser comentadas pelos usuários, através das páginas dos eventos ou via telefone. ${ }^{6}$ Essa é a única ferramenta disponibilizada pelo Portal que possibilita debates entre os participantes.

E as consultas públicas - que são o objeto desta pesquisa - permitem que os participantes apoiem ou rejeitem qualquer proposição legislativa que esteja em fase de tramitação no Senado Federal. Como há a necessidade de cadastro, o usuário pode votar uma única vez em cada proposição ${ }^{7}$.

\footnotetext{
${ }^{3}$ Há mais 22 proposições legislativas com mais de 50 mil votos, com a consulta pública ainda aberta, que não foram consideradas nesta pesquisa: PL 2630/2020, SUG 24/2018, PLS 515/2017, PL 2564/2020, SUG 2/2015, PLP 183/2019, PLS 116/2017, PLS 514/2017, SUG 9/2018, MPV 932/2020, PEC 186/2019, SUG 5/2016, PEC 51/2017, PLS 439/2015, PLS 495/2017, PLS 134/2018, MPV 905/2019, PEC 29/2015, PDL 98/2020, PLS 385/2016, PLC 30/2015, PLS 473/2017. Ver em: https://www.senado.gov.br/bi-arqs/Arquimedes/ecidadania/rel-consulta-publica-pdf.pdf. Acesso em 23 jun. 2020.

${ }^{4}$ Ver em: https://www12.senado.leg.br/ecidadania/sobre. Acesso em 27 jun. 2020.

${ }^{5}$ Ver em: https://www12.senado.leg.br/ecidadania/comofuncionaideia. Acesso em 27 jun. 2020.

${ }^{6}$ Ver em: https://www12.senado.leg.br/ecidadania/comofuncionaaudiencia. Acesso em 27 jun. 2020.

${ }^{7}$ Ver em: https://www12.senado.leg.br/ecidadania/comofuncionaconsultapublica. Acesso em 27 jun. 2020.
} 
FIGURA 1 - PORTAL E-CIDADANIA DO SENADO FEDERAL

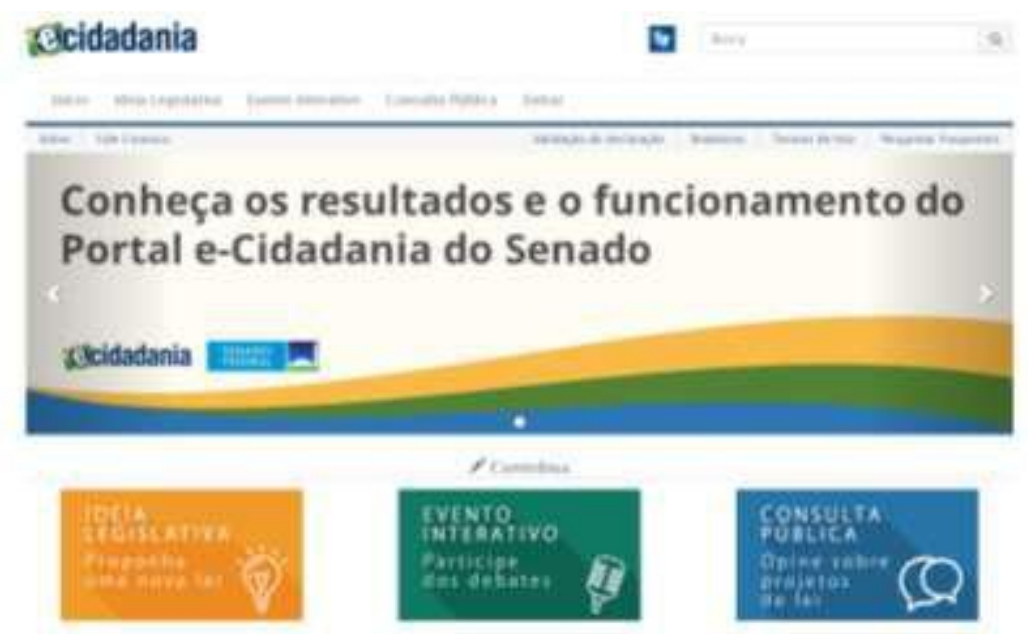

FONTE: Portal e-Cidadania do Senado Federal $(2020)^{8}$

As 41 proposições legislativas que já tiveram a consulta pública encerrada e que receberam mais de 50 mil votos dos usuários do Portal foram submetidas à Análise Documental, técnica na qual o pesquisador se vale de documentos originais (SÁ-SILVA, ALMEIDA, GUINDANI, 2009). O quadro abaixo, descreve as variáveis analisadas.

QUADRO 1 - VARIÁVEIS ANALISADAS

\begin{tabular}{|l|l|}
\hline \multicolumn{1}{|c|}{ Variável } & \multicolumn{1}{c|}{ Explicação da variável } \\
\hline Identificação & Número que identifica a proposição legislativa. \\
\hline Ementa & Texto que explica sobre o que trata a proposição legislativa. \\
\hline Número de apoios & Número de apoios recebidos pela proposição legislativa na consulta pública. \\
\hline Número de rejeições & Número de rejeições recebidas pela proposição legislativa na consulta pública. \\
\hline Autoria & Autor e partido da proposição legislativa. \\
\hline Situação & Último estado de tramitação da proposição legislativa. \\
\hline
\end{tabular}

FONTE: A autora (2020)

As variáveis "Número de apoios" e Número de rejeições" foram coletadas do próprio Portal e-Cidadania. Todas as demais variáveis estão disponíveis no Portal do Senado Federal, como mostra a Figura 2. Destaca-se que toda a coleta ocorreu no dia 22 de junho de 2020.

\footnotetext{
${ }^{8}$ Ver em: https://www12.senado.leg.br/ecidadania. Acesso em 27 jun. 2020. 


\section{FIGURA 2 - INFORMAÇÕES SOBRE PROPOSIÇÕES LEGISLATIVAS - PORTAL DO SENADO FEDERAL}

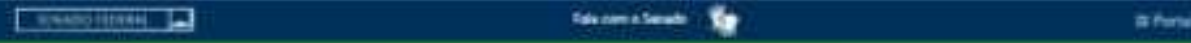

Atividade Legislativa

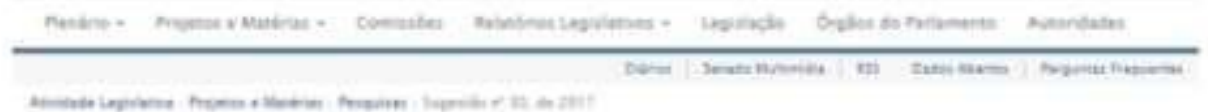

Sugestào n' 30 , de 2017

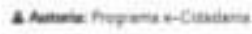

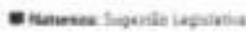
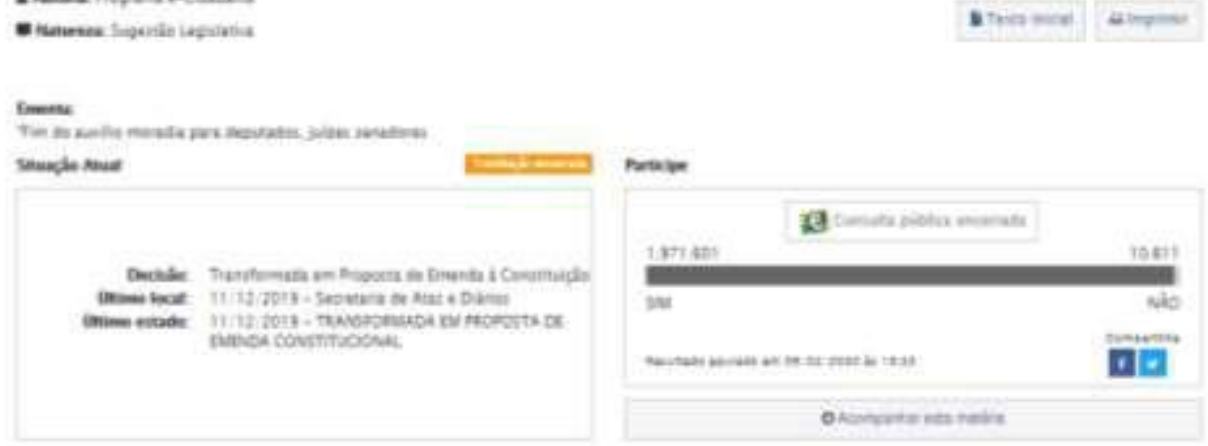

Docarmeition

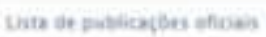

imfurmaçien compiemmars?

Mativias incionases

Tramitacis

FONTE: Portal do Senado Federal (2020) ${ }^{9}$

A seguir, são apresentados os resultados desta pesquisa.

\section{APRESENTAÇÃO DOS DADOS}

A Figura 3 apresenta o total de votos acumulados na Consulta Pública do Senado Federal, desde a sua criação. Até agora, 9.465 proposições legislativas já receberam mais 23 milhões de votos, vindos de cerca de 10 milhões de usuários. Esses resultados indicam que o Portal recebe a visita de cidadãos que se manifestam a respeito de mais de uma proposição legislativa.

\footnotetext{
${ }^{9}$ Ver em: https://www25.senado.leg.br/web/atividade/materias/-/materia/130204. Acesso em 27 jun. 2020. 

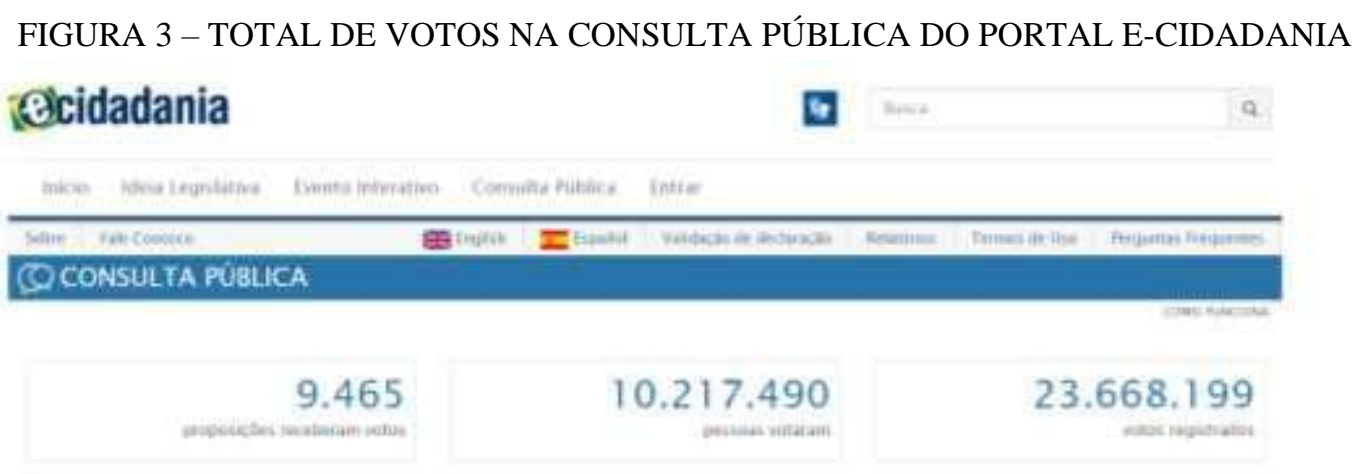

FONTE: Portal e-Cidadania do Senado Federal $(2020)^{10}$

O Gráfico 1 mostra que, até 2018, houve um crescimento exponencial na quantidade de votos e de votantes na Consulta Pública do Senado Federal.

Em 2013, 95 proposições receberam 1.429 votos de 602 participantes. No ano seguinte, o número de cidadãos votantes subiu para 67.357, o de votos para 143.547 e o de proposições para 803. Em 2015, 1.055 proposições receberam 214.045 votos de 99.519 cidadãos. Os anos de 2016, 2017 e 2018 apresentaram saltos ainda maiores. Mais de 4 milhões de votos foram contabilizados, em 2016, mais de 5 milhões, em 2017, e quase 8 milhões, em 2018. O número de votantes subiu de 2.347.007, em 2016, para 4.195.492, em 2018. No ano seguinte, a participação cai do Portal eCidadania: 3.087 proposições receberam 2.151.701 de 1.599.147 de cidadãos votantes. E, por fim, no ano de 2020, 2.585 proposições já receberam 3.227.783 votos de 2.496 .240 votantes.

${ }^{10}$ Ver em: https://www12.senado.leg.br/ecidadania/principalmateria. Acesso em 23 jun. 2020. 


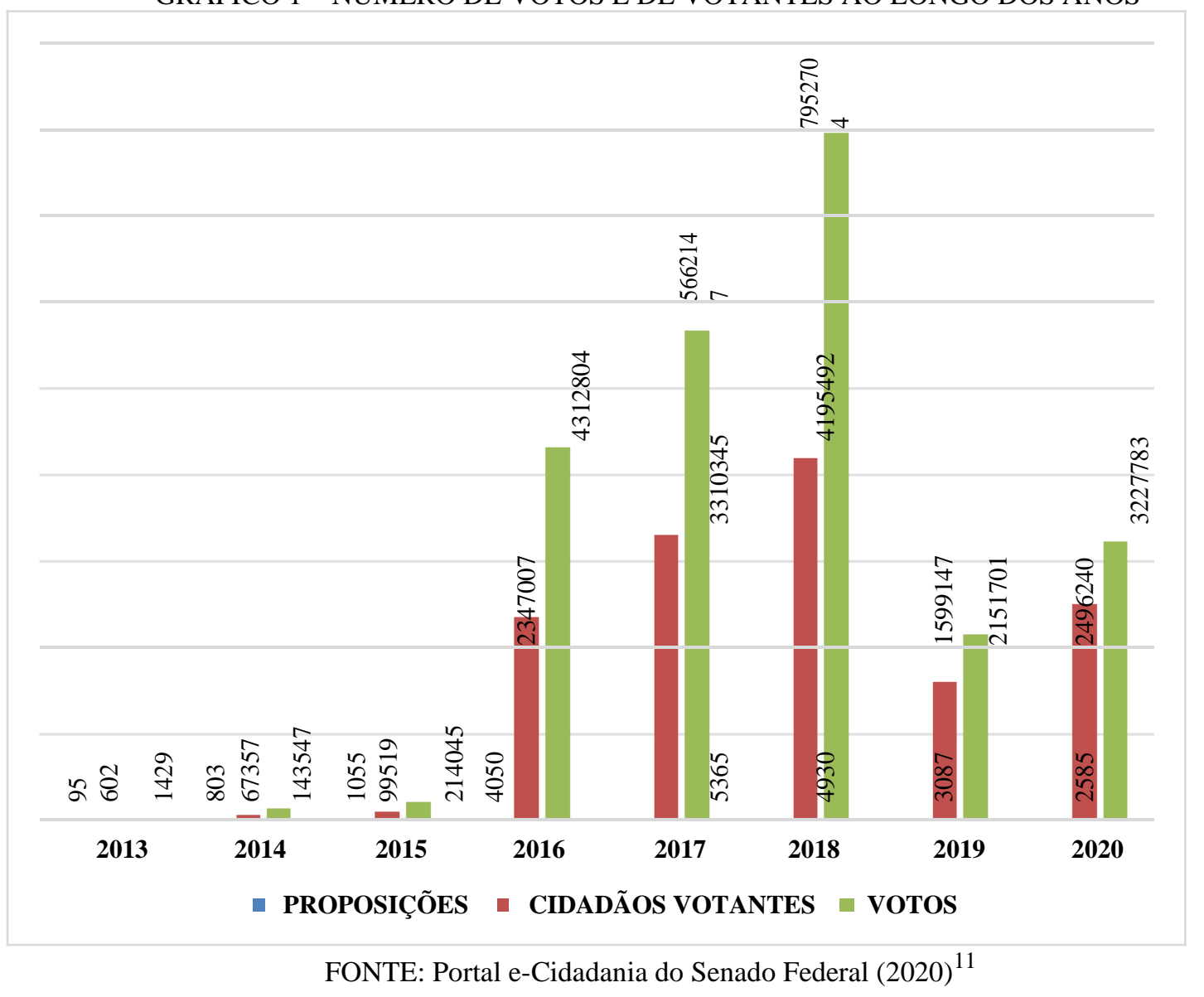

O Quadro 2 apresenta as 41 proposições legislativas que receberam mais de 50 mil votos na Consulta Pública do Senado Federal e já tiveram a votação encerrada. Nota-se que mais da metade delas (24) foi apresentada nos anos de 2016 e 2017 - o que pode explicar a grande quantidade de votos e de votantes, entre 2016 e 2018.

Destaca-se que, dentre as 41 matérias apresentadas, 16 consistem em sugestões legislativas, ou seja, são proposições enviadas pelos próprios usuários do Portal e-Cidadania que receberam pelo menos 20 mil apoios, em até quatro meses, e foram, portanto, encaminhadas à Comissão de Direitos Humanos e Legislação Participativa (CDH).

Registra-se também que as proposições que recebem mais atenção dos usuários tendem a tratar de temas controversos e recorrentes no debate público: cortes de gastos com a classe política (SUG 30/2017, SUG 16/2017, SUG 4/2017 e PEC 106/2015); porte de armas (PDS 175/2017 e PLS 378/2017); descriminalização do aborto (SUG 15/2014); questões relacionadas aos direitos da população LGBTQI+ (SUG 66/2017 e PDS 106/2013); descriminalização do cultivo ou do uso

\footnotetext{
${ }^{11}$ Ver em: https://www.senado.gov.br/bi-arqs/Arquimedes/ecidadania/rel-consulta-publica-pdf.pdf. Acesso em 23 jun. 2020 .
} 
recreativo da cannabis (SUG 25/2017 e SUG 8/2014) e criminalização de movimentos sociais (SUG 2/2018 e SUG 24/2017).

É importante também observar que algumas das proposições mais votadas foram amplamente divulgadas e debatidas por instituições jornalísticas. Um exemplo disso é a PEC 55/2016, proposta por Michel Temer (MDB) ${ }^{12}$, que recebeu mais de 350 mil votos. A chamada PEC do teto dos gastos públicos instituiu um novo regime fiscal que limita o crescimento das despesas do Poder Executivo Federal por $20 \operatorname{anos}^{13}$. Outro exemplo é o PLS 193/2016, também conhecido como "escola sem partido" ${ }^{14}$, que recebeu mais de 400 mil votos.

Recentemente, o presidente Jair Bolsonaro editou a MPV 979/2020, que permitia que o então Ministro da Educação, Abraham Weintraub, escolhesse os reitores das Universidades Federais, durante o período da pandemia do coronavírus. A MP foi amplamente noticiada pelas instituições midiáticas ${ }^{15}$ e, em poucos dias, recebeu 89.352 rejeições e 53.448 apoios no Portal e-Cidadania.

QUADRO 2 - PROPOSIÇÕES LEGISLATIVAS QUE RECEBERAM MAIS DE 50 MIL VOTOS NA CONSULTA PÚBLICA DO SENADO FEDERAL

\begin{tabular}{|c|c|c|c|c|c|c|}
\hline Identificação & Ementa & Apoios & Rejeições & Total & Autoria & Situação \\
\hline SUG 30/2017 & $\begin{array}{l}\text { Fim do auxílio moradia para } \\
\text { deputados, juízes senadores. }\end{array}$ & 1.971.601 & 10.611 & 1.982 .212 & $\begin{array}{l}\text { Programa e- } \\
\text { Cidadania }\end{array}$ & $\begin{array}{c}\text { Transformada } \\
\text { na PEC } \\
222 / 2019 \\
\end{array}$ \\
\hline $\begin{array}{c}\text { PEC } \\
106 / 2015\end{array}$ & $\begin{array}{l}\text { Dá nova redação aos artigos } 45 \\
\text { e } 46 \text { da Constituição Federal } \\
\text { para reduzir o número } r \\
\text { membros da } \\
\text { Deputados e do Senado Federal. }\end{array}$ & 1.859.115 & 10.699 & 1.869 .814 & $\begin{array}{c}\text { Vários } \\
\text { senadores }\end{array}$ & $\begin{array}{l}\text { Arquivada ao } \\
\text { final da } \\
\text { legislatura }\end{array}$ \\
\hline $\begin{array}{c}\text { PDS } \\
175 / 2017\end{array}$ & $\begin{array}{l}\text { Convoca plebiscito sobre a } \\
\text { revogação do Estatuto do } \\
\text { Desarmamento. }\end{array}$ & 731.679 & 950.220 & 1.681 .899 & $\begin{array}{c}\text { Vários } \\
\text { senadores }\end{array}$ & $\begin{array}{l}\text { Retirada pelo } \\
\text { autor }\end{array}$ \\
\hline SUG 2/2018 & $\begin{array}{l}\text { Criminalizar o MST, MTST e } \\
\text { outros movimentos ditos sociais } \\
\text { que invadem propriedades. }\end{array}$ & 521.017 & 388.888 & 909.905 & $\begin{array}{l}\text { Programa e- } \\
\text { Cidadania }\end{array}$ & $\begin{array}{l}\text { Rejeitada em } \\
\text { Comissão }\end{array}$ \\
\hline
\end{tabular}

$12 \quad$ Ver $\quad$ em: $\quad<$ https://brasil.elpais.com/brasil/2016/10/10/politica/1476125574_221053.html>, <https://economia.uol.com.br/noticias/redacao/2019/09/05/teto-de-gastos-constituicao-calculo-limite-gastos〈https://www.gazetadopovo.com.br/instituto-politeia/pec-do-teto-de-gastos/>, <https://www.poder360.com.br/tag/pec-do-teto-dos-gastos-publicos/>. Acesso em 23 jun. 2020.

13 Ver em: http://www.planalto.gov.br/ccivil 03/constituicao/Emendas/Emc/emc95.htm. Acesso em 23 jun. 2020.

14 Ver em: <https://g1.globo.com/educacao/noticia/entenda-a-polemica-em-torno-do-escola-sem-partido.ghtml>, $<$ https://brasil.elpais.com/brasil/2016/06/22/politica/1466631380_123983.html>, <https://exame.abril.com.br/brasil/5opinioes-sobre-a-escola-sem-partido-para-voce-formar-a-sua/>. Acesso em 23 jun. 2020.

${ }^{15}$ Ver em: < https://g1.globo.com/educacao/noticia/2020/06/10/bolsonaro-edita-mp-que-permite-weintraub-escolherreitores-temporarios-de-universidades-federais-durante-a-pandemia.ghtml $>,<$ https://www.correiobraziliense.com.br/app/noticia/eu-estudante/ensino_ensinosuperior/2020/06/10/internaensinosuperior-2019,862671/bolsonaro-edita-mp-que-autoriza-weintraub-a-escolher-reitores.shtml $>,<$ https://noticias.band.uol.com.br/noticias/100000992181/bolsonaro-edita-mp-que-permite-weintraub-escolher-reitorestemporarios.html>. Acesso em 23 jun. 2020. 


\begin{tabular}{|c|c|c|c|c|c|c|}
\hline SUG 15/2014 & $\begin{array}{l}\text { Regular a interrupção voluntária } \\
\text { da gravidez, dentro das doze } \\
\text { primeiras semanas de gestação, } \\
\text { pelo sistema único de saúde. }\end{array}$ & 423.403 & 381.116 & 804.519 & $\begin{array}{l}\text { Programa e- } \\
\text { Cidadania }\end{array}$ & $\begin{array}{l}\text { Arquivada ao } \\
\text { final da } \\
\text { legislatura }\end{array}$ \\
\hline $\begin{array}{c}\text { MPV } \\
914 / 2019\end{array}$ & 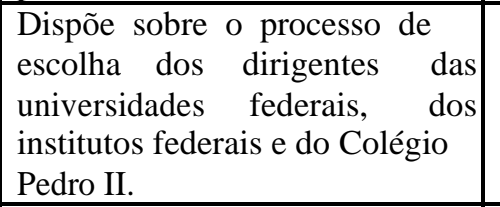 & 297.983 & 413.617 & 711.600 & $\begin{array}{l}\text { Presidência } \\
\text { da República }\end{array}$ & $\begin{array}{l}\text { Perdeu } \\
\text { eficácia }\end{array}$ \\
\hline $\begin{array}{c}\text { PDS } \\
106 / 2013\end{array}$ & $\begin{array}{l}\text { Susta os efeitos da Resolução } n^{\circ} \\
175 \text {, de 2013, do Conselho } \\
\text { Nacional de Justiça, que dispõe } \\
\text { sobre a habilitaçâo, celebração } \\
\text { de casamento civil, ou de } \\
\text { conversão de união estável em } \\
\text { casamento, entre pessoas de } \\
\text { mesmo sexo. }\end{array}$ & 28.964 & 430.121 & 459.085 & $\begin{array}{l}\text { Senador } \\
\text { Magno } \\
\text { Malta } \\
\text { (PL/ES) }\end{array}$ & $\begin{array}{l}\text { Arquivada ao } \\
\text { final da } \\
\text { legislatura }\end{array}$ \\
\hline SUG 11/2017 & $\begin{array}{l}\text { Anistia ao Senhor } \text { Deputado } \\
\text { Federal Jair Messias Bolsonaro }\end{array}$ & 223.094 & 221.432 & 444.526 & $\begin{array}{c}\text { Programa e- } \\
\text { Cidadania } \\
\end{array}$ & $\begin{array}{l}\text { Rejeitada em } \\
\text { Comissão }\end{array}$ \\
\hline $\begin{array}{c}\text { PLS } \\
193 / 2016\end{array}$ & $\begin{array}{l}\text { Inclui entre as diretrizes e bases } \\
\text { da educação nacional, de que } \\
\text { trata a Lei no } 9.394 \text {, de } 20 \text { de } \\
\text { dezembro de } 1996 \text {, o "Programa } \\
\text { Escola sem Partido". }\end{array}$ & 199.873 & 210.819 & 410.692 & $\begin{array}{l}\text { Senador } \\
\text { Magno } \\
\text { Malta } \\
\text { (PL/ES) }\end{array}$ & $\begin{array}{l}\text { Retirada pelo } \\
\quad \text { autor }\end{array}$ \\
\hline PEC 55/2016 & $\begin{array}{lr}\text { Altera o Ato das } & \text { Disposições } \\
\text { Constitucionais } & \text { Transitórias, } \\
\text { para instituir o Novo Regime } \\
\text { Fiscal, e dá outras providências. }\end{array}$ & 23.766 & 345.654 & 369.420 & $\begin{array}{l}\text { Presidência } \\
\text { da República }\end{array}$ & $\begin{array}{c}\text { Transformada } \\
\text { em norma } \\
\text { jurídica }\end{array}$ \\
\hline SUG 24/2017 & $\begin{array}{l}\begin{array}{l}\text { Criminalização da apologia ao } \\
\text { comunismo. }\end{array} \\
\end{array}$ & 176.711 & 175.373 & 352.084 & $\begin{array}{c}\text { Programa e- } \\
\text { Cidadania } \\
\end{array}$ & $\begin{array}{l}\text { Rejeitada em } \\
\text { Comissão }\end{array}$ \\
\hline PLC 28/2017 & 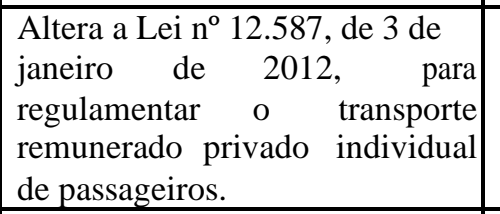 & 44.857 & 262.113 & 306.970 & $\begin{array}{l}\text { Deputado } \\
\text { Federal } \\
\text { Carlos } \\
\text { Zarattini } \\
\text { (PT/SP) } \\
\end{array}$ & $\begin{array}{l}\text { Transformada } \\
\text { em norma } \\
\text { jurídica }\end{array}$ \\
\hline $\begin{array}{c}\text { PLS } \\
280 / 2016\end{array}$ & $\begin{array}{l}\text { Define os crimes de abuso de } \\
\text { autoridade e dá outras } \\
\text { providências. }\end{array}$ & 4.671 & 277.463 & 282.134 & $\begin{array}{l}\text { Senador } \\
\text { Renan } \\
\text { Calheiros } \\
\text { (MDB/AL) } \\
\end{array}$ & $\begin{array}{l}\text { Prejudicada } \\
\text { em virtude de } \\
\text { aprovação de } \\
\text { substitutivo } \\
\end{array}$ \\
\hline $\begin{array}{c}\text { PLS } \\
445 / 2012\end{array}$ & $\begin{array}{l}\text { Concede isenção do Imposto de } \\
\text { Renda sobre a remuneração de } \\
\text { professores, nas condições que } \\
\text { estabelece. }\end{array}$ & 272.112 & 7.642 & 279.754 & $\begin{array}{l}\text { Senador } \\
\text { Sérgio } \\
\text { Petecão } \\
\text { (PSD/AC) } \\
\end{array}$ & $\begin{array}{l}\text { Arquivada ao } \\
\text { final da } \\
\text { legislatura }\end{array}$ \\
\hline PEC 20/2016 & \begin{tabular}{lccc|} 
Insere artigo & no & Ato & das \\
Disposições & \multicolumn{2}{c|}{ Constitucionais } \\
Transitórias, & para & prever & a \\
realização & de & eleições \\
presidenciais & simultaneamente \\
às eleições municipais de 2016.
\end{tabular} & 202.996 & 16.581 & 219.577 & $\begin{array}{l}\text { Vários } \\
\text { senadores }\end{array}$ & $\begin{array}{l}\text { Arquivada ao } \\
\text { final da } \\
\text { legislatura }\end{array}$ \\
\hline $\begin{array}{c}\text { PLS } \\
350 / 2014\end{array}$ & $\begin{array}{l}\text { Altera a Lei } \mathrm{n}^{\circ} 12.842 \text {, de } 10 \text { de } \\
\text { julho de } 2013 \text {, que dispõe sobre } \\
\text { o exercício da Medicina, para } \\
\text { modificar as atividades } \\
\text { privativas de médico. }\end{array}$ & 76.820 & 114.696 & 191.516 & $\begin{array}{l}\text { Senadora } \\
\text { Lúcia Vânia } \\
\text { (PSDB/GO) }\end{array}$ & $\begin{array}{l}\text { Retirada pelo } \\
\quad \text { autor }\end{array}$ \\
\hline PLC 38/2017 & $\begin{array}{l}\text { Altera a Consolidação das Leis } \\
\text { do Trabalho (CLT), aprovada } \\
\text { pelo Decreto-Lei n }{ }^{\circ} 5.452 \text {, de } 1^{\circ} \\
\text { de maio de } 1943, \text { e as Leis } n^{\circ} \mathrm{s}\end{array}$ & 16.789 & 172.166 & 188.955 & $\begin{array}{l}\text { Presidência } \\
\text { da República }\end{array}$ & $\begin{array}{l}\text { Transformada } \\
\text { em norma } \\
\text { jurídica }\end{array}$ \\
\hline
\end{tabular}




\begin{tabular}{|c|c|c|c|c|c|c|}
\hline & $\begin{array}{l}6.019 \text {, de } 3 \text { de janeiro de } 1974, \\
8.036 \text {, de } 11 \text { de maio de } 1990, \text { e } \\
8.212 \text {, de } 24 \text { de julho de } 1991, \text { a } \\
\text { fim de adequar a legislação às } \\
\text { novas relações de trabalho. }\end{array}$ & & & & & \\
\hline SUG 20/2018 & $\begin{array}{llr}\text { Pela obrigatoriedade } & \text { das } \\
\text { disciplinas de Filosofia } & \text { e } \\
\text { Sociologia no Ensino Médio. } & \end{array}$ & 141.620 & 19.560 & 161.180 & $\begin{array}{l}\text { Programa e- } \\
\text { Cidadania }\end{array}$ & $\begin{array}{c}\text { Transformada } \\
\text { no PL } \\
2579 / 2019\end{array}$ \\
\hline SUG 15/2017 & $\begin{array}{l}\text { Reduzir os impostos sobre } \\
\text { games dos atuais } 72 \% \text { para } 9 \% .\end{array}$ & 156.189 & 552 & 156.741 & $\begin{array}{c}\text { Programa e- } \\
\text { Cidadania }\end{array}$ & $\begin{array}{c}\text { Transformada } \\
\text { na PEC } \\
51 / 2017\end{array}$ \\
\hline $\begin{array}{c}\text { MPV } \\
979 / 2020\end{array}$ & $\begin{array}{l}\text { Dispõe sobre a designação de } \\
\text { dirigentes pro tempore para as } \\
\text { instituições federais de ensino } \\
\text { durante o período da } \\
\text { emergência de saúde pública de } \\
\text { importância internacional } \\
\text { decorrente da pandemia da } \\
\text { covid-19, de que trata a Lei no } \\
13.979 \text {, de } 6 \text { de fevereiro de } \\
2020 \text {. }\end{array}$ & 53.448 & 89.352 & 142.800 & $\begin{array}{l}\text { Presidência } \\
\text { da República }\end{array}$ & $\begin{array}{l}\text { Perdeu } \\
\text { eficácia }\end{array}$ \\
\hline SUG 25/2017 & $\begin{array}{l}\text { Descriminalização do cultivo da } \\
\text { cannabis para uso próprio. }\end{array}$ & 126.387 & 13.891 & 140.278 & $\begin{array}{l}\text { Programa e- } \\
\text { Cidadania }\end{array}$ & $\begin{array}{c}\text { Transformada } \\
\text { no PLS } \\
514 / 2017\end{array}$ \\
\hline $\begin{array}{c}\text { PL } \\
2362 / 2019\end{array}$ & $\begin{array}{l}\text { Revoga o Capítulo IV - Da } \\
\text { Reserva Legal, da Lei no } 12.651 \text {, } \\
\text { de } 25 \text { de maio de } 2012 \text {, que } \\
\text { dispõe sobre a proteção da } \\
\text { vegetação nativa, para garantir o } \\
\text { direito constitucional de } \\
\text { propriedade. }\end{array}$ & 3.724 & 129.230 & 132.954 & $\begin{array}{l}\text { Senadores } \\
\text { Flávio } \\
\text { Bolsonaro } \\
\text { (PSL/RJ) e } \\
\text { Marcio } \\
\text { Bittar } \\
\text { (MDB/AC) }\end{array}$ & $\begin{array}{l}\text { Retirada pelo } \\
\text { autor }\end{array}$ \\
\hline $\begin{array}{c}\text { PLS } \\
378 / 2017\end{array}$ & $\begin{array}{l}\text { Dispõe sobre a fabricação, } \\
\text { importação, comercialização, } \\
\text { registro, posse e porte de armas } \\
\text { de fogo e munição em todo o } \\
\text { território nacional. }\end{array}$ & 106.750 & 16.742 & 123.492 & $\begin{array}{l}\text { Senador } \\
\text { Wilder } \\
\text { Morais } \\
(\mathrm{PP} / \mathrm{GO})\end{array}$ & $\begin{array}{l}\text { Arquivada ao } \\
\text { final da } \\
\text { legislatura }\end{array}$ \\
\hline $\begin{array}{c}\text { PL } \\
1615 / 2019\end{array}$ & $\begin{array}{l}\text { Dispõe sobre a classificação da } \\
\text { visão monocular r como } \\
\text { deficiência sensorial, do tipo } \\
\text { visual, assegurando a pessoa } \\
\text { com visão monocular os } \\
\text { mesmos direitos e benefícios } \\
\text { previstos na legislação para a } \\
\text { pessoa com deficiência. }\end{array}$ & 108.288 & 1.045 & 109.333 & $\begin{array}{c}\text { Senadores } \\
\text { Rogério } \\
\text { Carvalho } \\
\text { (PT/SE), } \\
\text { Rose de } \\
\text { Freitas } \\
\text { (PODEMOS } \\
\text { /ES), } \\
\text { Wellington } \\
\text { Fagundes } \\
\text { (PL/MT) e } \\
\text { Otto Alencar } \\
\text { (PSD/BA) }\end{array}$ & $\begin{array}{l}\text { Remetida à } \\
\text { Câmara dos } \\
\text { Deputados }\end{array}$ \\
\hline $\begin{array}{c}\text { MPV } \\
657 / 2014\end{array}$ & $\begin{array}{l}\text { Altera a Lei } \mathrm{n}^{\circ} 9.266 \text {, de } 15 \text { de } \\
\text { março de } 1996 \text {, que reorganiza } \\
\text { as classes da Carreira Policial } \\
\text { Federal, fixa a remuneração dos } \\
\text { cargos que as integram e dá } \\
\text { outras providências. }\end{array}$ & 4.235 & 103.081 & 107.316 & $\begin{array}{l}\text { Presidência } \\
\text { da República }\end{array}$ & $\begin{array}{l}\text { Transformada } \\
\text { em norma } \\
\text { jurídica }\end{array}$ \\
\hline SUG 66/2017 & $\begin{array}{l}\text { Retificação de registro civil } \\
\text { transexuais. }\end{array}$ & 84.711 & 17.085 & 101.796 & $\begin{array}{l}\text { Programa e- } \\
\text { Cidadania }\end{array}$ & $\begin{array}{c}\text { Transformada } \\
\text { no PL } \\
2745 / 2019 \\
\end{array}$ \\
\hline
\end{tabular}




\begin{tabular}{|c|c|c|c|c|c|c|}
\hline SUG 4/2017 & $\begin{array}{l}\text { Fim do Estatuto do } \\
\text { Desarmamento. }\end{array}$ & 90.013 & 5.596 & 95.609 & $\begin{array}{c}\text { Programa e- } \\
\text { Cidadania }\end{array}$ & $\begin{array}{c}\text { Rejeitada em } \\
\text { Comissão }\end{array}$ \\
\hline SUG 34/2018 & $\begin{array}{l}\text { Aumento retroativo e anual das } \\
\text { bolsas de pós-graduação. }\end{array}$ & 89.203 & 3.311 & 92.514 & $\begin{array}{l}\text { Programa e- } \\
\text { Cidadania }\end{array}$ & $\begin{array}{c}\text { Transformada } \\
\text { em PL } \\
3612 / 2019 \\
\end{array}$ \\
\hline SUG 17/2017 & $\begin{array}{l}\text { Criminalização do Funk como } \\
\text { crime de saúde pública a criança } \\
\text { aos adolescentes e a família. }\end{array}$ & 52.858 & 38.477 & 91.335 & $\begin{array}{l}\text { Programa e- } \\
\text { Cidadania }\end{array}$ & $\begin{array}{l}\text { Rejeitada em } \\
\text { Comissão }\end{array}$ \\
\hline SUG 7/2017 & $\begin{array}{l}\text { Torna falsa acusação de estupro } \\
\text { crime hediondo e inafiançável. }\end{array}$ & 41.269 & 40.185 & 81.454 & $\begin{array}{c}\text { Programa e- } \\
\text { Cidadania }\end{array}$ & $\begin{array}{l}\text { Rejeitada em } \\
\text { Comissão }\end{array}$ \\
\hline $\begin{array}{c}\text { MPV } \\
746 / 2016\end{array}$ & $\begin{array}{l}\text { Institui a Política de Fomento à } \\
\text { Implementação de Escolas de } \\
\text { Ensino Médio em Tempo } \\
\text { Integral, altera a Lei no } 9.394 \text {, de } \\
20 \text { de dezembro de } 1996 \text {, que } \\
\text { estabelece as diretrizes e bases } \\
\text { da educação nacional, e a Lei no } \\
11.494 \text { de } 20 \text { de junho } 2007 \text {, que } \\
\text { regulamenta o Fundo de } \\
\text { Manutenção e Desenvolvimento } \\
\text { da Educação Básica e de } \\
\text { Valorizaçâo dos Profissionais } \\
\text { da Educação, e dá outras } \\
\text { providências. }\end{array}$ & 4.551 & 73.554 & 78.105 & $\begin{array}{l}\text { Presidência } \\
\text { da República }\end{array}$ & $\begin{array}{l}\text { Transformada } \\
\text { em norma } \\
\text { jurídica }\end{array}$ \\
\hline PEC 50/2016 & 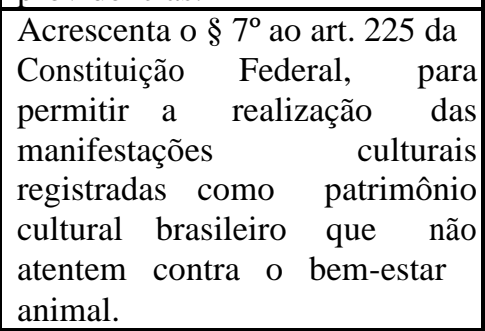 & 13.789 & 63.391 & 77.180 & $\begin{array}{l}\text { Vários } \\
\text { senadores }\end{array}$ & $\begin{array}{c}\text { Transformada } \\
\text { em norma } \\
\text { jurídica }\end{array}$ \\
\hline PLC 24/2016 & $\begin{array}{l}\text { Eleva o Rodeio, a Vaquejada, } \\
\text { bem como as respectivas } \\
\text { expressões artístico-culturais, à } \\
\text { condição de manifestação } \\
\text { cultural nacional e de } \\
\text { patrimônio cultural imaterial. }\end{array}$ & 17.479 & 51.486 & 68.965 & $\begin{array}{l}\text { Deputado } \\
\text { Federal } \\
\text { Capitão } \\
\text { Augusto } \\
\text { (PL/SP) }\end{array}$ & $\begin{array}{l}\text { Transformada } \\
\text { em norma } \\
\text { jurídica }\end{array}$ \\
\hline SUG 8/2014 & $\begin{array}{l}\text { Regular o uso recreativo, } \\
\text { medicinal e industrial da } \\
\text { maconha. }\end{array}$ & 63.266 & 3.940 & 67.206 & $\begin{array}{l}\text { Programa e- } \\
\text { Cidadania }\end{array}$ & $\begin{array}{l}\text { Aprovado } \\
\text { parecer do } \\
\text { relator }\end{array}$ \\
\hline $\begin{array}{c}\text { MPV } \\
805 / 2017\end{array}$ & $\begin{array}{l}\text { Posterga ou cancela aumentos } \\
\text { remuneratórios para os } \\
\text { exercícios subsequentes, altera a } \\
\text { Lei } \mathrm{n}^{\circ} 8.112 \text {, de } 11 \text { de dezembro } \\
\text { de } 1990 \text {, que dispõe sobre o } \\
\text { regime jurídico dos servidores } \\
\text { públicos civis da União, das } \\
\text { autarquias e das fundações } \\
\text { públicas federais, e a Lei } \mathrm{n}^{\circ} \\
10.887 \text {, de } 18 \text { de junho de } 2004, \\
\text { quanto à alíquota da } \\
\text { contribuição social do servidor } \\
\text { público e a outras questões. }\end{array}$ & 1.785 & 61.597 & 63.382 & $\begin{array}{l}\text { Presidência } \\
\text { da República }\end{array}$ & $\begin{array}{l}\text { Perdeu e } \\
\text { eficácia }\end{array}$ \\
\hline PEC 51/2013 & $\begin{array}{l}\text { Altera os arts. } 21,24 \text { e } 144 \text { da } \\
\text { Constituição; acrescenta os arts. } \\
\text { 143-A, 144-A e 144-B, } \\
\text { reestrutura } 0 \text { modelo de }\end{array}$ & 27.386 & 31.561 & 58.947 & $\begin{array}{l}\text { Vários } \\
\text { senadores }\end{array}$ & $\begin{array}{l}\text { Arquivada ao } \\
\text { final da } \\
\text { legislatura }\end{array}$ \\
\hline
\end{tabular}




\begin{tabular}{|c|c|c|c|c|c|c|}
\hline & $\begin{array}{l}\text { segurança pública a partir da } \\
\text { desmilitarização do modelo } \\
\text { policial. }\end{array}$ & & & & & \\
\hline $\begin{array}{c}\text { PLS } \\
612 / 2011\end{array}$ & $\begin{array}{l}\text { Altera os arts. } 1.723 \text { e } 1.726 \text { do } \\
\text { Código Civil, para permitir o } \\
\text { reconhecimento legal da união } \\
\text { estável entre pessoas do mesmo } \\
\text { sexo. }\end{array}$ & 43.659 & 13.234 & 56.893 & $\begin{array}{l}\text { Senadora } \\
\text { Marta } \\
\text { Suplicy } \\
\text { (PT/SP) }\end{array}$ & $\begin{array}{l}\text { Arquivada ao } \\
\text { final da } \\
\text { legislatura }\end{array}$ \\
\hline PEC 10/2013 & $\begin{array}{l}\text { Altera os arts. } 102,105,108 \text { e } \\
125 \text { da Constituição Federal } \\
\text { para extinguir o foro especial } \\
\text { por prerrogativa de função nos } \\
\text { casos de crimes comuns. }\end{array}$ & 56.511 & 187 & 56.698 & $\begin{array}{c}\text { Vários } \\
\text { senadores }\end{array}$ & $\begin{array}{l}\text { Remetida à } \\
\text { Câmara dos } \\
\text { Deputados }\end{array}$ \\
\hline SUG 16/2017 & $\begin{array}{l}\text { Fim da aposentadoria especial } \\
\text { para Senadores e Deputados. }\end{array}$ & 52.568 & 66 & 52.634 & $\begin{array}{l}\text { Programa e- } \\
\text { Cidadania }\end{array}$ & $\begin{array}{c}\text { Prejudicada } \\
\text { em virtude da } \\
\text { aprovação de } \\
\text { outra } \\
\text { sugestão } \\
\text { legislativa }\end{array}$ \\
\hline SUG 18/2017 & $\begin{array}{l}\text { Referendo pela Restauração da } \\
\text { Monarquia Parlamentarista no } \\
\text { Brasil. }\end{array}$ & 44.686 & 6.244 & 50.930 & $\begin{array}{l}\text { Programa e- } \\
\text { Cidadania }\end{array}$ & $\begin{array}{l}\text { Rejeitada em } \\
\text { Comissão }\end{array}$ \\
\hline PEC 18/2017 & $\begin{array}{l}\text { Altera a Constituição Federal } \\
\text { para instituir o voto facultativo } \\
\text { nas eleições. }\end{array}$ & 47.770 & 2.295 & 50.065 & $\begin{array}{c}\text { Vários } \\
\text { senadores }\end{array}$ & $\begin{array}{l}\text { Arquivada ao } \\
\text { final da } \\
\text { legislatura }\end{array}$ \\
\hline
\end{tabular}

FONTE: Portal e-Cidadania (2020)

Abaixo, o Gráfico 2 pretende facilitar a visualização de alguns resultados já expostos no Quadro 2.

Dentre as 24 proposições que receberam maior número de apoios do que de rejeições, nove ainda permanecem em tramitação e uma foi prejudicada em virtude de matéria semelhante. As demais não tiveram o desfecho que a maior parte dos votantes esperava: sete foram rejeitadas e sete foram arquivadas.

As proposições com maior número de apoios que ainda permanecem em tramitação são: 1) SUG 30/2017, que pede o fim do auxílio moradia para juízes e deputados; 2) SUG 20/2018, que versa sobre a obrigatoriedade das disciplinas de Filosofia e Sociologia no Ensino Médio; 3) SUG 15/2017, que propõe a redução de imposto sobre jogos eletrônicos; 4) SUG 25/2017, que propõe a descriminalização do cultivo da cannabis; 5) PL 1615/2019, que versa sobre deficiência visual; 6) SUG 66/2017, que facilita a troca do nome de registro pelo nome social para pessoas transexuais; 7) SUG 34/2018, que propõe o aumento retroativo e anual de bolsas de pós-graduação; 8) SUG 8/2014, que versa sobre o uso recreativo da maconha; e 9) PEC 10/2013, que extingue foro especial.

As sugestões 30/2017, 20/2018, 15/2017, 25/2017, 66/2017 e 34/2018 foram aprovadas pela Comissão de Direitos Humanos e Legislação Participativa (CDH) e hoje tramitam como PEC 222/2019, PL 2579/19, PEC 51/2017, PLS 514/2017, PLS 2745/2019 e PL 3612/2019, 
respectivamente. A PEC 222/2019 ainda aguarda relator na Comissão de Constituição de Justiça $(\mathrm{CCJ})^{16}$. O PL 2579/2019 recebeu parecer favorável do relator Romário (PODE) e aguarda ser discutido pela Comissão de Educação, Cultura e Esporte ${ }^{17}$. A PEC 51/2017 foi aprovada pela CCJ e, desde agosto de 2019, está pronta para ser votada pelo Plenário ${ }^{18}$. O PLS 514/2017 também recebeu parecer favorável da senadora Marta Suplicy (MDB) e aguarda o parecer do relator Lasier Martins (PODE) ${ }^{19}$. E o PL 3612/2019, que recebeu parecer contrário do relator Izalci Lucas (PSDB), aguarda a votação da Comissão de Assuntos Econômicos 20 .

A SUG 8/2014 aguarda audiência pública, requerida pelo relator Cristovam Buarque (PDT), em 2015; o PLS 2745/2019 aguarda designação do relator na Comissão de Constituição, Justiça e Cidadania, desde maio de 2019; e a PEC 10/2013 ainda tramita na Câmara dos Deputados, como PEC 333/2017. O que esses resultados mostram é que, mesmo que parte das proposições com maior número de apoios no Portal e-Cidadania ainda esteja em tramitação, algumas estão estagnadas.

A sugestão 16/2017 (que propunha o fim da aposentadoria especial para Senadores e Deputados) foi prejudicada devido à aprovação da SUG 43/2017, de mesmo teor (hoje tramita como PEC 53/2019) ${ }^{21}$.

As proposições com maior número de apoios no Portal e-Cidadania e que foram rejeitadas são: 1) SUG 2/2018 (propunha a criminalização de movimentos sociais como p MST e o MTST); 2) SUG 11/2017 (propunha anistia ao então Deputado Federal Jair Bolsonaro em relação às ofensas proferidas à Deputada Maria do Rosário, do $\mathrm{PT}^{22}$ ); 3) SUG 24/2017 (sugeria a criminalização do comunismo); 4) SUG 4/2017 (propunha o fim do estatuto do desarmamento); 5) SUG 17/2017 (sugeria a criminalização do funk); 6) SUG 7/2017 (sugeria que a falsa acusação de estupro deveria ser crime hediondo e inafiançável); e 7) SUG 18/2017 (apelava para o retorno do regime monarquista no Brasil). Todas elas foram rejeitadas pela Comissão de Direitos Humanos e Legislação Participativa (CDH).

A PEC 106/2015, que propunha reduzir o número de membros da Câmara dos Deputados e do Senado Federal, proposta por vários senadores de diversos partidos, começou a tramitar em julho de 2017, recebeu parecer favorável do relator Randolfe Rodrigues (REDE), mas foi arquivada ao

\footnotetext{
${ }^{16}$ Ver em: https://www25.senado.leg.br/web/atividade/materias/-/materia/140184. Acesso em 23 jun. 2020.

${ }^{17}$ Ver em: https://www25.senado.leg.br/web/atividade/materias/-/materia/136527. Acesso em 23 jun. 2020.

${ }^{18}$ Ver em: https://www25.senado.leg.br/web/atividade/materias/-/materia/132049. Acesso em 23 jun. 2020.

${ }^{19}$ Ver em: https://www25.senado.leg.br/web/atividade/materias/-/materia/132047. Acesso em 23 jun. 2020.

${ }^{20}$ Ver em: https://www25.senado.leg.br/web/atividade/materias/-/materia/137355. Acesso em 23 jun. 2020.

21 Ver em: https://www25.senado.leg.br/web/atividade/materias/-/materia/129169. Acesso em 23 jun. 2020.

22 Ver em: https://www1.folha.uol.com.br/poder/2014/12/1559815-para-rebater-deputada-bolsonaro-diz-que-nao-aestupraria.shtml. Acesso em 23 jun. 2020.
} 
término da legislatura $^{23}$. A SUG 15/2014, que dispunha sobre a descriminalização do aborto, foi designada ao relator Margo Malta (PL), que votou pelo arquivamento da proposta - o que ocorreu ao final da legislatura ${ }^{24}$. A PLS 445/2012 sugeria conceder isenção de imposto de renda a professores e passou ainda mais tempo em tramitação - foi apresentada em 2012, recebeu parecer contrário da relatora Maria do Carmo Alves (DEM) e foi arquivada no final de $2018^{25}$. A PEC 20/2016, que previa eleições presidenciais e municipais simultâneas, começou a tramitar em abril de 2016, recebeu dois pareceres contrários a sua aprovação e foi arquivada ao final da legislatura, em dezembro de $2018^{26}$. O PLS 378/2017, que propunha a flexibilização do porte e da posse de armas no país, recebeu parecer favorável do senador Sérgio Petecão (PSD), mas foi arquivado ao final da legislatura, em dezembro de $2018^{27}$. O PLS 612/2011, que propunha a alteração do Código Civil a fim de permitir o reconhecimento legal da união entre pessoas do mesmo sexo, tramitou por quase sete anos e recebeu pareceres favoráveis dos relatores Lídice de Mata (PSB) e Roberto Requião (MDB), mas também foi arquivado ao final da legislatura, em $2018^{28}$. E a PEC $18 / 2017$, que sugeria o voto facultativo, foi arquivada sem nunca ter sido designada a um relator ${ }^{29}$.

\footnotetext{
${ }^{23}$ Ver em: https://www25.senado.leg.br/web/atividade/materias/-/materia/122432. Acesso em 23 jun. 2020.

${ }^{24}$ Ver em: https://www25.senado.leg.br/web/atividade/materias/-/materia/119431. Acesso em 23 jun. 2020.

25 Ver em: https://www25.senado.leg.br/web/atividade/materias/-/materia/109603. Acesso em 23 jun. 2020.

${ }^{26}$ Ver em: https://www25.senado.leg.br/web/atividade/materias/-/materia/125574. Acesso em 23 jun. 2020.

${ }^{27}$ Ver em: https://www25.senado.leg.br/web/atividade/materias/-/materia/131130. Acesso em 23 jun. 2020.

${ }^{28}$ Ver em: https://www25.senado.leg.br/web/atividade/materias/-/materia/102589. Acesso em 23 jun. 2020.

${ }^{29}$ Ver em: https://www25.senado.leg.br/web/atividade/materias/-/materia/129157. Acesso em 23 jun. 2020.
} 
GRÁFICO 2 - SITUAÇÃO DAS PROPOSIÇÕES LEGISLATIVAS

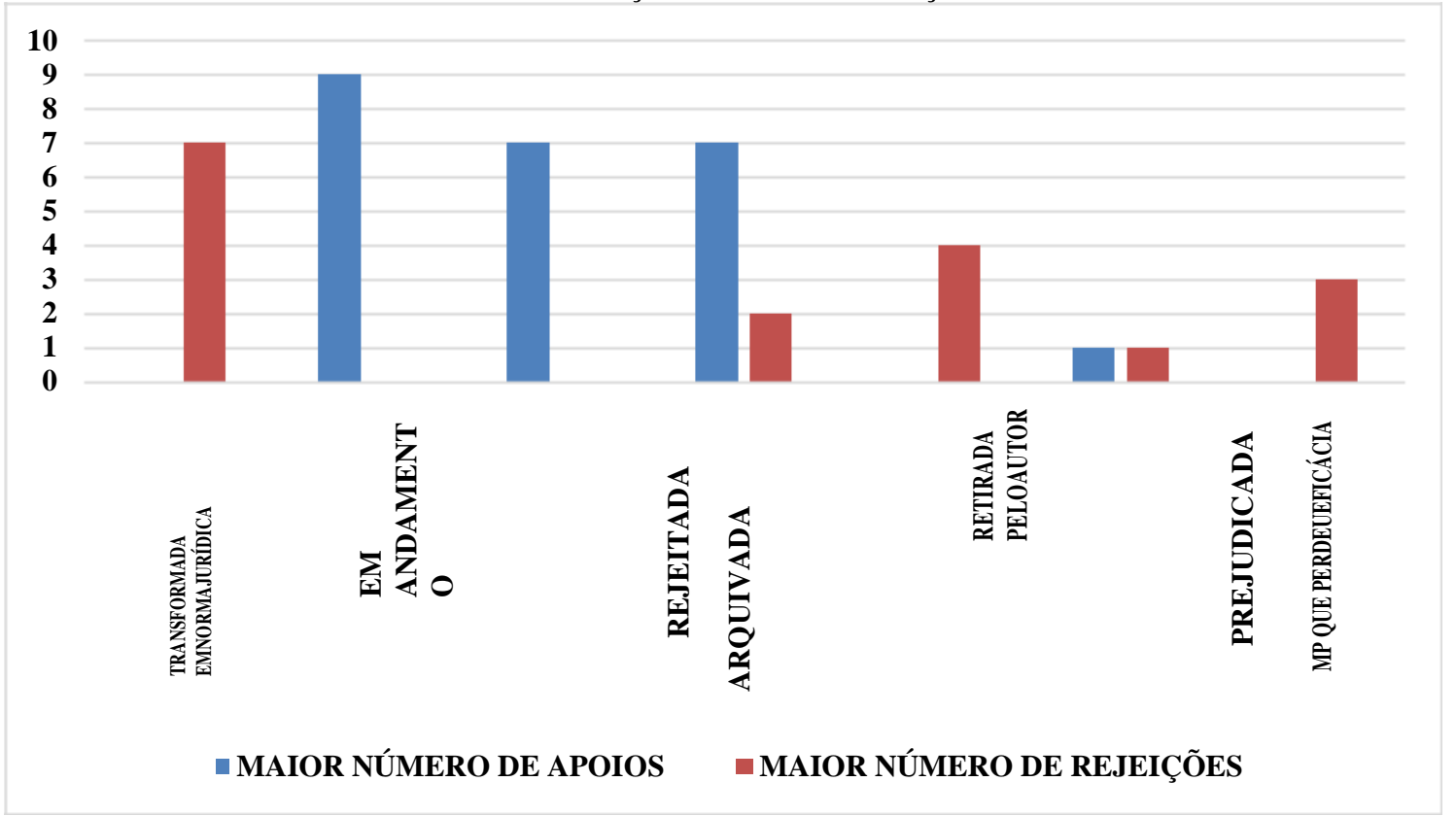

FONTE: Portal e-Cidadania (2020)

Em relação às 17 proposições legislativas que receberam maior número de rejeições, sete foram transformadas em normas jurídicas e uma foi prejudicada por aprovação de substitutivo. As outras nove proposições tiveram desfecho condizente com a opinião dos votantes: duas foram arquivadas, quatro foram retiradas pelo autor, e três Medidas Provisórias perderam eficácia.

As proposições transformadas em normas jurídicas são: 1) a PEC do Teto dos gastos públicos (55/2016), que hoje consiste na Emenda Constitucional $n^{\circ} 95^{30}$; 2) o PLC 28/2017, transformado na Lei 13.640/2018, que regula o transporte remunerado privado individual de $\operatorname{passageiros}^{31}$; 3) o PLC 38/2017, hoje Lei 13.467/2017, que altera a Consolidação das Leis do Trabalho (CLT), conhecida como Reforma Trabalhista ${ }^{32}$; 4) a MPV 657/2014, convertida na Lei 13.047/2014, que dispõe sobre a carreira policial federal ${ }^{33}$; 5) a MPV 746/2016, hoje Lei 13.415/2017, que estabelece diretrizes para a educação nacional ${ }^{34}$; 6) a PEC 50/2016, chamada de PEC da vaquejada, que gerou a Emenda Constitucional $n^{\circ} 96 / 2017^{35}$, e 7 ) o PLC 24/2016, hoje Lei 13.364, que reconhece o rodeio, a vaquejada e o laço como manifestações culturais nacionais ${ }^{36}$.

\footnotetext{
${ }^{30}$ Ver em: http://www.planalto.gov.br/ccivil_03/constituicao/emendas/emc/emc95.htm. Acesso em 23 jun. 2020.

${ }^{31}$ Ver em: http://www.planalto.gov.br/ccivil 03/ Ato2015-2018/2018/Lei/L13640.htm. Acesso em 23 jun. 2020.

${ }^{32}$ Ver em: http://www.planalto.gov.br/ccivil_03/ ato2015-2018/2017/lei/113467.htm. Acesso em 23 jun. 2020.

33 Ver em: http://www.planalto.gov.br/ccivil 03/ato2011-2014/2014/lei/L13047.htm. Acesso em 23 jun. 2020.

${ }^{34}$ Ver em: http://www.planalto.gov.br/ccivil_03/ ato2015-2018/2017/lei/113415.htm. Acesso em 23 jun. 2020.

35 Ver em: https://legis.senado.leg.br/norma/17703519/publicacao/17703528. Acesso em 23 jun. 2020.

${ }^{36}$ Ver em: http://www.planalto.gov.br/ccivil_03/_ato2015-2018/2016/lei/L13364.htm. Acesso em 23 jun. 2020.
} 
O PLS 280/2016, que definia crimes de abuso de autoridade, foi prejudicado em virtude de aprovação de substitutivo que tramitava em conjunto, o PLS 85/2017 $7^{37}$.

As propostas arquivadas foram o PDS 106/2013 e a PEC 51/2013. O primeiro, apresentado por Magno Malta, sugeria sustar a Resolução $\mathrm{n}^{\mathbf{0}}$ 175, de 2013, que impede que autoridades competentes se recusem a realizar casamento ou união estável entre pessoas do mesmo sexo ${ }^{38}$. Ela tramitou por quase cinco anos e foi arquivada em 2018 ao final da legislatura ${ }^{39}$. A PEC 51/2013, que propunha a desmilitarização das polícias, chegou a receber parecer positivo de Randolfe Rodrigues (REDE), mas foi arquivada em $2018^{40}$.

As propostas retiradas pelos próprios autores foram o PDS 175/2017, o PLS 193/2016, o PLS 350/2014 e PL 2362/2019. O primeiro sugeria a convocação de um novo plebiscito para revisar o Estatuto do Desarmamento e chegou a receber parecer favorável do relator Sérgio Petecão (PSD/AC), mas mesmo assim foi retirado pelos autores em novembro de $2018^{41}$. O PLS 193/2016, de autoria de Magno Malta, que propunha o Programa Escola sem Partido. Vale destacar que o movimento ainda existe $^{42}$ e outras matérias sobre o tema tramitam no Congresso Nacional, como o PL 867/2015, do Deputado Federal Izalci Lucas (PSDB) ${ }^{43}$. O PLS 350/2014, que propunha mudanças na lei que versa sobre o exercício da Medicina (12842/2013), tramitou por dois anos e foi retirado pela autora Lúcia Vânia (PSDB), em agosto de $2016^{44}$. E o PL 2362/2019, que sugeria mudanças no Código Florestal para que áreas de reserva legal pudessem ser exploradas economicamente, recebeu parecer favorável do relator Roberto Rocha (PSDB), mas foi retirado pelos autores Flávio Bolsonaro e Marcio Bittar ${ }^{45}$.

A seguir, são discutidos os principais achados desta pesquisa.

\section{CONSIDERAÇÕES FINAIS}

Os dados apresentados na seção anterior mostram que, no que tange às proposições que receberam maior número de apoios, a maioria não foi concluída pelos legisladores da forma como os

\footnotetext{
${ }^{37}$ Ver em: https://www25.senado.leg.br/web/atividade/materias/-/materia/126377. Acesso em 23 jun. 2020.

${ }^{38}$ Ver em: https://atos.cnj.jus.br/atos/detalhar/1754. Acesso em 24 jan. 2020.

${ }^{39}$ Ver em: https://www25.senado.leg.br/web/atividade/materias/-/materia/112745. Acesso em 23 jun. 2020.

${ }^{40}$ Ver em: https://www25.senado.leg.br/web/atividade/materias/-/materia/114516. Acesso em 23 jun. 2020.

${ }^{41}$ Ver em: https://www25.senado.leg.br/web/atividade/materias/-/materia/130695. Acesso em 23 jun. 2020.

${ }^{42}$ Ver em: http://escolasempartido.org/. Acesso em 23 jun. 2020.

${ }^{43}$ Ver em: https://www.camara.leg.br/proposicoesWeb/fichadetramitacao?idProposicao=1050668. Acesso em 23 jun. 2020.

${ }^{44}$ Ver em: https://www25.senado.leg.br/web/atividade/materias/-/materia/119167. Acesso em 23 jun. 2020.

${ }^{45}$ Ver em: https://www25.senado.leg.br/web/atividade/materias/-/materia/136371
} 
participantes do Portal e-Cidadania esperavam. Das 24 matérias, sete foram arquivadas e sete foram rejeitadas. Nove ainda permanecem em tramitação, mas algumas estão estagnadas há algum tempo. Nenhuma das matérias com maior número de apoios foi transformada em norma jurídica.

Em relação às 17 proposições legislativas que receberam maior número de rejeições, o resultado é um pouco mais positivo para os participantes da consulta pública. Duas foram arquivadas, quatro foram retiradas pelo autor, e três Medidas Provisórias perderam eficácia - o que pode ser um indício de atores políticos levando em consideração a opinião dos cidadãos. Os autores que retiraram suas proposições, por exemplo, podem ter sido constrangidos pela reprovação dos participantes das consultas públicas. E, novamente, destaca-se o caso da Medida Provisória 979, editada por Jair Bolsonaro, que foi devolvida pelo Senado Federal e, em seguida, revogada pelo governo, após críticas de agentes políticos e de mais de 89 mil rejeições no Portal e-Cidadania ${ }^{46}$.

Em contrapartida, sete proposições que receberam maior número de rejeições foram transformadas em normas jurídicas.

No geral, os resultados indicam que as decisões dos legisladores são pouco condizentes com os votos nas consultas públicas: dentre as 41 proposições analisadas, mais da metade (23) tiveram um desfecho oposto daquele sugerido pelos cidadãos participantes. Esses resultados confirmam que, muitas vezes, as manifestações dos cidadãos não são, de fato, consideradas pelos agentes públicos (FARIA, 2012; MARQUES, 2010; FUNG, 2006, STROMER-GALLEY, 2000). Contudo, nem sempre isso configura em perdas democráticas, como será analisado mais abaixo.

Chama a atenção que, entre as 41 proposições mais votadas, 16 são sugestões legislativas. Ou seja, os usuários do Portal e-Cidadania estão se manifestando a respeito das ideias enviadas pelos cidadãos. Além disso, seis sugestões legislativas foram aprovadas pela Comissão de Direitos Humanos e Legislação Participativa $(\mathrm{CDH})$ e hoje tramitam como projetos de lei ou propostas de emenda à Constituição. Mitozo e Marques (2019) destacam que é importante que as plataformas de participação política concedam algum poder de agenda aos participantes, o que parece estar ocorrendo na Consulta Pública do Senado Federal.

Entretanto, é preocupante que algumas sugestões enviadas pelos usuários busquem restringir as liberdades democráticas, como a SUG 2/2018, que sugeriu criminalizar movimentos sociais como o MST e o MTST; a SUG 24/2017, que propôs a criminalização do comunismo; a SUG 17/2017, que propôs a criminalização do funk; e a SUG 18/2017, que sugeriu um referendo pela restauração da

\footnotetext{
46 Ver em: https://www.camara.leg.br/noticias/668526-presidente-do-congresso-devolve-mp-que-permitia-nomeacaode-reitores-sem-consulta-as-universidades/. Acesso em 29 jun. 2020.
} 
Monarquia no Brasil. Destaca-se também a SUG 7/2017, que propôs tornar a falsa acusação de estupro crime hediondo e inafiançável, o que, muito provavelmente, dificultaria as denúncias de violência sexual no Brasil. Vale relembrar que todas essas sugestões receberam maior número de apoios do que de rejeições. Esses resultados corroboram a perspectiva de Gomes (2011), que afirma que participar não consiste em um valor democrático em si mesmo, participar torna-se um valor democrático quando busca produzir benefícios para toda a comunidade política. Além disso, o autor tem enfatizado que, desde as manifestações de 2013, o Brasil vivencia um processo de hiperparticipação, no qual pessoas com pouco conhecimento do sistema político e que, até pouco tempo, não tinham interesse por política, passam a participar de forma "radical e equivocada" e a reivindicar políticas públicas não democráticas ${ }^{47}$.

Ressalta-se também que, apesar do crescimento exponencial nos últimos anos, o número de participantes das consultas públicas do Senado Federal ainda é restrito, se considerado o número de brasileiros com acesso à internet. De acordo com a pesquisa TIC Domicílios 2018, realizada pela CETIC (2019), e que investiga o uso das tecnologias de informação e comunicação no Brasil, 67\% dos domicílios brasileiros possuem acesso à internet - sendo que em áreas urbanas, nas regiões Sul e Sudeste e no caso de famílias com renda mensal superior a dois salários mínimos, as porcentagens são ainda mais altas. Ou seja, não obstante, cerca de 126 milhões de brasileiros terem acesso às plataformas digitais, pouco mais de 10 milhões já participaram ao menos uma vez das consultas públicas disponibilizadas pelo Senado Federal. A baixa participação pode ser um indício de que poucos cidadãos se interessam em participar, pode ocorrer porque os brasileiros não sentem que suas manifestações serão consideradas pelos agentes públicos (FARIA, 2012) e também é provável que a maior parte da população sequer conheça a plataforma.

Levando em consideração os critérios de avaliação de consultas públicas online, propostos por Barros (2016), nota-se que a ferramenta do Senado Federal falha ao não promover ambientes de debate entre os participantes e pouco oferece recursos sistêmicos, ou seja, as matérias em votação não são traduzidas para linguagem leiga. Mesmo com a disposição da ementa e da explicação da ementa, que consistem em resumos das proposições legislativas, em alguns casos e para alguns participantes, pode ficar difícil compreender amplamente o que as matérias propõem.

Ressalta-se que esta pesquisa tem limitações por analisar apenas 41 propostas. Trabalhos futuros podem ampliar a discussão com a expansão do corpus ou com o emprego de outros métodos

\footnotetext{
47 Ver em: <http://www.cienciaecultura.ufba.br/agenciadenoticias/noticias/de-olho-no-xadrez-eleitoral-de-2018/>, $<$ https://revistacult.uol.com.br/home/seminario-cult-sociedade-hiperinformada/>. Acesso em 29 jun. 2020.
} 
de pesquisa - como surveys aplicados aos participantes das consultas públicas e aos atores políticos, por exemplo.

\section{REFERÊNCIAS}

AGGIO, Camilo; SAMPAIO, Rafael Cardoso. Democracia digital e participação: os modelos de consulta e os desafios do Gabinete Digital. In: COCCO, Giuseppe (org.). Gabinete digital: análise de uma experiência. Porto Alegre: Companhia Rio-grandense de Artes Gráfica (CORAG), 2013

ALMADA, Maria Paula; CARREIRO, Rodrigo, BARROS, Samuel, GOMES, Wilson. Democracia digital no Brasil: obrigação legal, pressão política e viabilidade tecnológica. MATRIZes, vol. 13, n. 3, p. 161-181, 2019.

BARROS, Samuel. Os desafios das consultas públicas online: lições do Marco Civil da Internet. Liinc em Revista, vol. 12, n. 1, p. 72-89, 2016.

CETIC. TIC Domicílios: Pesquisa sobre o Uso das Tecnologias de Informação e Comunicação nos Domicílios Brasileiros - 2018. São Paulo: Comitê Gestor da Internet no Brasil, 2019.

Disponível em: https://cetic.br/publicacao/pesquisa-sobre-o-uso-das-tecnologias-de-informacao-ecomunicacao-nos-domicilios-brasileiros-tic-domicilios-2018/. Acesso em: 27/06/2020.

CHRISTENSEN, Henrik Serup. Political activities on the internet: slacktivism or political participation by other means? First Monday, vol. 16, n. 2, 2011.

FARIA, Cristiano Ferri Soares de. O Parlamento aberto na era da internet: Pode o povo colaborar com o Legislativo na elaboração das leis? Brasília: Câmara dos Deputados, Edições Câmara, 2012.

FARIA, Cristiano Ferri Soares de; REHBEIN, Malena. A política de parlamento aberto: uma análise crítica da Câmara Federal brasileira. Anais do Congresso CONSAD de Gestão Pública, p. 1-32, Maio de 2015.

FREITAS, Christina Soares de; LIMA, Fernanda Fiuza; LIMA, Fernanda Queiroz. Os Desafios ao Desenvolvimento de um Ambiente para Participação Política Digital: o Caso de uma Comunidade Virtual Legislativa do Projeto e-Democracia no Brasil. Organizações \& Sociedade, vol. 22, n. 75, 2015.

FUNG, Archon. Varieties of Participation in Complex Governance. Public Administration Review, p. 66-75, 2006.

GOMES, Wilson. A democracia no mundo digital: história, problemas e temas. São Paulo: Edições SESC, 2018.

GOMES, Wilson. Participação política online: Questões e hipóteses de trabalho. In: MAIA, Rousiley Celi Moreira; GOMES, Wilson; MARQUES, Francisco Paulo Jamil Almeida. Internet e Participação Política no Brasil. Porto Alegre: Editora Sulina, 2011. 
GOMES, Wilson. A democracia digital e o problema da participação civil na decisão política. Revista Fronteiras - Estudos Midiáticos, vol. 7, n. 3, p. 214-222, 2005.

KLANG, Mathias; MADISON, Nora. The domestication of online activism. First Monday, vol. 21, n. 6, 2016.

KOVIC, Marko; RAUCHFLEISCH, Adrian; SELE, Marc; CASPAR, Christian. Digital astroturfing in politics: definition, typology, and countermeasures. Studies in Communication Sciences, vol. 18 , n. $1,2018$.

MARQUES, Francisco Paulo Jamil Almeida. "Muro baixo, o povo pula": iniciativas institucionais de participação digital e seus desafios fundamentais. Opinião Pública, vol. 16, n. 1, p.117-142, 2010.

MITOZO, Isabele; MARQUES, Francisco Paulo Jamil Almeida. Context Matters! Looking Beyond Platform Structure to Understand Citizen Deliberation on Brazil's Portal e-Democracia. Policy \& Internet, 2019.

MITOZO, Isabele; MARQUES, Francisco Paulo Jamil Almeida; MONT’ALVERNE, Camila. Como se configura a comunicação online entre representantes e representados no Brasil? Um estudo sobre as ferramentas digitais da Câmara dos Deputados. Contracampo, vol. 35, n. 2, p. 87-115, 2016.

SÁ-SILVA, Jackson Ronie; ALMEIDA, Cristóvão Domingos de; GUINDANI, Joel Felipe. Pesquisa documental: pistas teóricas e metodológicas. Revista Brasileira de História \& Ciências Sociais, n. 1, 2009.

SILVA, Daniel Reis. Astroturfing: lógicas e dinâmicas de manifestações de públicos simulados. Belo Horizonte: FAFICH/Selo PPGCOM/UFMG, 2015.

SHIPLEY, Robert; UTZ, Stephen. Making it Count: A Review of the Value and Techniques for Public Consultation. Journal of Planning Literature, 2011.

STROMER-GALLEY, Jennifer. Online Interaction and Why Candidates Avoid It. Journal of Communication, vol. 50, n. 4, p. 111-132, 2000.

VAN-DETH, Jan. W. Political participation. In: MAZZOLENI, Gianpietro. The international encyclopedia of political communication. John Wiley \& Sons, 2015. 